\title{
Dechlorosoma suillum Achenbach et al. 2001 is a later subjective synonym of Azospira oryzae Reinhold-Hurek and Hurek 2000
}

Correspondence

Barbara Reinhold-Hurek

breinhold@uni-bremen.de

\section{Zhiyuan Tan and Barbara Reinhold-Hurek}

University of Bremen, Faculty of Biology and Chemistry, Laboratory of General Microbiology, PO Box 3304 40, D-28334 Bremen, Germany
The genera Azoarcus, Azospira, Azovibrio and Azonexus form phylogenetically distinct branches within the Rhodocyclus rDNA cluster of the $\beta$-subclass of the Proteobacteria (Reinhold-Hurek \& Hurek, 2000). Azospira oryzae consists of nitrogen-fixing bacteria that occur as endophytes of grass roots, especially rice (Engelhard et al., 2000), and in association with fungi (Reinhold-Hurek \& Hurek, 2000). In the original description, they were assigned to the genus Azoarcus sensu lato (group D) (Reinhold-Hurek et al., 1993). Partial and almost complete sequences of their 16S rRNA genes were respectively published by Hurek \& ReinholdHurek (1995) and Hurek et al. (1997a). Cells of Azospira oryzae are motile rods that grow mostly on salts of organic acids and have a strictly respiratory metabolism with oxygen or nitrate as terminal electron acceptors.

Recently, bacteria that are capable of dissimilatory (per)chlorate reduction have been isolated from a wide range of environmental samples (Coates et al., 1999; Michaelidou et al., 2000). For four closely related isolates with $16 \mathrm{~S}$ rDNA phylogenetic distances ranging from 0 to $0 \cdot 12 \%$, a new genus, Dechlorosoma gen. nov., was proposed that was reported to be phylogenetically most closely related to Rhodocyclus (Achenbach et al., 2001). Strain PS $^{\mathrm{T}}$ was described as the type strain of Dechlorosoma suillum sp. nov. (Achenbach et al., 2001). Bacteria of this species have a strictly respiratory metabolism with oxygen, nitrate or (per)chlorate as terminal electron acceptors.

In the phylogenetic trees published by Achenbach et al. (2001) and Coates et al. (2001), Azospira was not included; however, $16 \mathrm{~S}$ rDNA sequences of $D$. suillum show highest similarity to Azospira oryzae. In order to clarify the taxonomic relationships between Azospira oryzae and D. suillum, we carried out a polyphasic taxonomic analysis that suggested that these bacteria belong to the same species, $D$. suillum being a later subjective synonym of Azospira oryzae.

The type strain of D. suillum, DSM $13638^{\mathrm{T}}$, was received from the DSMZ. Azospira oryzae strains $6 \mathrm{a}^{\mathrm{T}}$ (=LMG $9096^{\mathrm{T}}$ ) and OM8A-5 and Azovibrio restrictus OSB2-4 were revived from stocks stored in liquid nitrogen in our laboratory. Unless stated otherwise, all strains were grown at $37^{\circ} \mathrm{C}$ on VM ethanol medium (Reinhold-Hurek \& Hurek, 2000).

Biotype 100 strips and API 20E systems with medium 2 (bioMérieux) were used to determine substrate utilization patterns and enzyme profiles. Both strips were inoculated according to the manufacturer's instructions. Growth was recorded after 1, 2, 4 and 7 days incubation at $30^{\circ} \mathrm{C}$ (Reinhold-Hurek \& Hurek, 2000). Data recorded at day 4 are given; they did not differ from recordings at day 7 . Perchlorate reduction was tested by anaerobic culturing techniques as described previously (Bruce et al., 1999; Coates et al., 1999). For the medium, solutions A (1000 ml), B $(10 \mathrm{ml})$ and C $(10 \mathrm{ml})$ (http://www.dsmz.de/media/ med908.htm) were autoclaved separately and anaerobically under $\mathrm{N}_{2} / \mathrm{CO}_{2}(90: 10)$. Dissolved $\mathrm{O}_{2}$ was removed from the medium by boiling. Vitamin solution $(5 \mathrm{ml})$ and trace element solution SL-10 (1 ml) (http://www.dsmz.de/media/ med908.htm), as well as sodium salts of acetate and chlorate (10 $\mathrm{mM}$ each) as the electron donor and acceptor (Coates et al., 1999), were added. 
For protein patterns, cells were grown on VM ethanol plates for $36 \mathrm{~h}$ at $37^{\circ} \mathrm{C}$. Extraction of SDS-soluble proteins and electrophoresis conditions were described before (Reinhold-Hurek \& Hurek, 2000).

For Southern hybridization, genomic DNA was extracted (Hurek et al., 1993) from D. suillum DSM $13638^{\mathrm{T}}$ and Azospira oryzae $63^{\mathrm{T}}$ and digested separately with restriction enzymes EcoRI and PstI. Fragments were separated by agarose gel electrophoresis, transferred onto nylon filter membranes and hybridized to a DNA probe labelled with digoxigenin (Roche). The nifH gene probe was generated by PCR with primer pair TH25/TH26 from a plasmid carrying nifH of strain BH72 (Hurek et al., 1997b). Hybridization was carried out at medium stringency as described by Hurek et al. (1997b).

For gas-chromatographic detection of nitrogenase activity, strains were grown on semi-solid nitrogen-free SM medium (Reinhold et al., 1986) at $28{ }^{\circ} \mathrm{C}$ for 4 days. The acetylene reduction assay was carried out with $1 \%(\mathrm{v} / \mathrm{v})$ acetylene and the ethylene formed was quantified by using a gas chromatograph with flame-ionization detector (Karg \& Reinhold-Hurek, 1996).

For DNA-DNA hybridization, DNAs were extracted and purified according to the method of Marmur (1961). Levels of DNA relatedness were determined by the initial renaturation rate method (De Ley et al., 1970) as described previously (Reinhold-Hurek et al., 1993).

16S rDNA sequences obtained from the GenBank database were aligned by RDP (Ribosomal Database Project) (Maidak et al., 1999). Distances of the aligned sequences (corresponding to positions 56-1492 of the Escherichia coli $16 \mathrm{~S}$ rRNA gene) were calculated by the method of Jukes \& Cantor (1969). The tree topology was inferred by the neighbour-joining method (Saitou \& Nei, 1987) and the phylogenetic tree was constructed by using the TREECON software package (Van de Peer \& de Wachter, 1994).

As the description of $D$. suillum did not include a detailed analysis of carbon sources for growth or enzymic activities (Achenbach et al., 2001), we subjected D. suillum DSM $13638^{\mathrm{T}}$ and Azospira oryzae strains $6 \mathrm{a}^{\mathrm{T}}$ and OM8A-5 to a comparative analysis of 122 physiological and biochemical tests. All three strains showed identical characteristics. They used $\mathrm{D}(-)$-tartrate, $\mathrm{L}(-)$-malate, DL-lactate, succinate, fumarate, DL- $\beta$-hydroxybutyrate (3-hydroxybutyrate), L-aspartate, L-glutamate, propionate, 2-oxoglutarate, butyrate, acetate and ethanol as sole carbon sources. Except for these 13 positive reactions (butyrate, acetate and ethanol tests were not included in Biotype 100 strip), all strains tested could not use the other 89 carbon sources supplied in the Biotype 100 strip. These physiological features are in agreement with previous observations for Azospira oryzae (Reinhold-Hurek \& Hurek, 2000). All tested strains showed catalase, cytochrome $c$ oxidase and denitrification activity, but no gelatinase, tryptophan deaminase, urease, ornithine decarboxylase, lysine decarboxylase, arginine dihydrolase or $\beta$-galactosidase activity. No fermentation or oxidation of glucose, mannitol, inositol, sorbitol, rhamnose, sucrose, melibiose, amygdalin or arabinose occurred. These data demonstrated that D. suillum and Azospira oryzae have many physiological and biochemical characteristics in common. However, perchlorate reduction was only observed in D. suillum. In contrast to strain DSM $13638^{\mathrm{T}}$, Azospira oryzae strains $63^{\mathrm{T}}$ and OM8A-5 did not show significant growth within 4 days in the presence of perchlorate.

For comparison of profiles of SDS-soluble proteins, three strains (D. suillum DSM $13638^{\mathrm{T}}$, Azospira oryzae $6 \mathrm{a} 3^{\mathrm{T}}$ and Azovibrio restrictus OSB2-4) were used (Fig. 1a). D. suillum DSM $13638^{\mathrm{T}}$ and Azospira oryzae $63^{\mathrm{T}}$ had almost identical

(a)

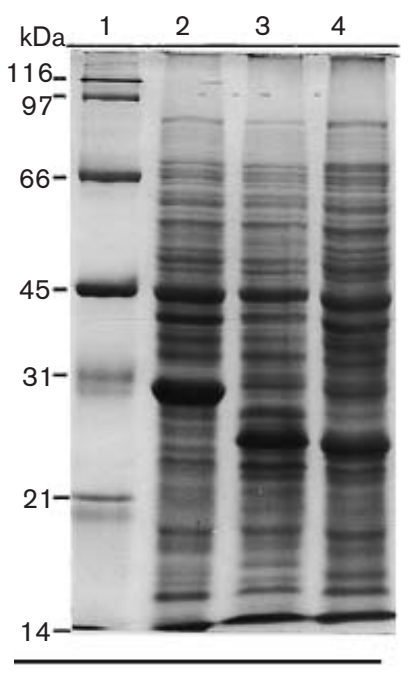

(b)

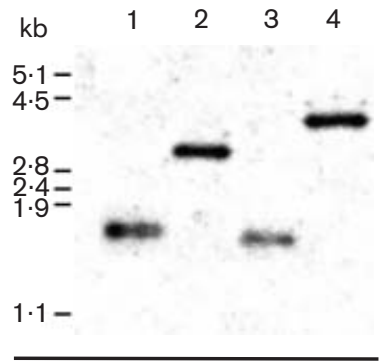

Fig. 1. (a) SDS-PAGE of SDS-soluble whole-cell proteins of D. suillum, Azospira oryzae and Azovibrio restrictus strains. Lanes: 1, molecular-mass standards; 2, Azovibrio restrictus OSB2-4; 3, D. suillum DSM $13638^{\top} ; 4$, Azospira oryzae $63^{\top}$. (b) Detection of a nifH gene homologue by Southern blot hybridization. Total DNA of bacteria digested with EcoRl (lanes 1 and 3) or Pstl (lanes 2 and 4) was hybridized with a digoxigenin-labelled nifH gene probe from Azoarcus sp. strain $\mathrm{BH} 72$ at medium stringency. Lanes 1 and $2, D$. suillum DSM $13638^{\top}$; lanes 3 and 4, Azospira oryzae $6 \mathrm{a}^{\top}$. 
protein patterns. As a negative control, extracts of cells of a different diazotrophic member of the Rhodocyclus-group, Azovibrio restrictus OSB2-4, were significantly different.

Strains of Azospira oryzae were originally isolated from roots of Kallar grass and several species of rice under conditions of nitrogen fixation. Diazotrophy is a main feature of this genus and species. However, this feature had not been tested for D. suillum (Achenbach et al., 2001). Southern hybridization of D. suillum DSM $13638^{\mathrm{T}}$ with a nifH gene probe (Fig. 1b) indicated that this strain also harbours a nifH-homologous gene, albeit with a slight restriction fragment length polymorphism in comparison with Azospira oryzae $63^{\mathrm{T}}$. Reduction of acetylene $\left(\mathrm{C}_{2} \mathrm{H}_{2}\right)$ to ethylene $\left(\mathrm{C}_{2} \mathrm{H}_{4}\right)$ was detected by gas chromatography after 2-4 days of growth of strain DSM $13638^{\mathrm{T}}$ in semi-solid $\mathrm{N}$-free medium. This suggests that the nifH gene is functional and nitrogenase is present in D. suillum.

A phylogenetic analysis of the 16S rRNA genes of Azospira oryzae, D. suillum and related genera showed that Azospira oryzae and D. suillum were located in the same branch and formed a lineage distinct from others, supported by bootstrap values of 100 or $61 \%$ (Fig. 2). The similarity of the 16S rDNA sequences of Azospira oryzae and D. suillum was $99.9 \%$, with only 2 bp different in $1435 \mathrm{bp}$. These data suggested that Dechlorosoma is highly related to Azospira.

The similarity level of DNA-DNA hybridization is crucial for assessment of bacterial species identity (Stackebrandt \& Goebel, 1994). DNA-DNA hybridizations were performed between DNA of strains DSM $13638^{\mathrm{T}}, 6 \mathrm{a} 3^{\mathrm{T}}$ and OM8A-5. Respective similarity levels of 90 and $92 \%$ were recorded between strains DSM $13638^{\mathrm{T}}$ and OM8A-5 and strains DSM $13638^{\mathrm{T}}$ and $6 \mathrm{a} 3^{\mathrm{T}}$. The high DNA relatedness, of more

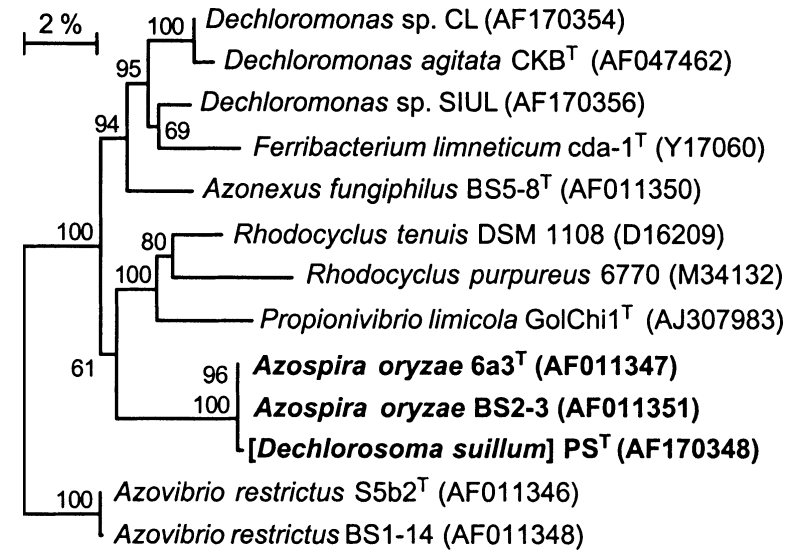

Fig. 2. Phylogenetic tree of Azospira oryzae, D. suillum and related genera. The tree was constructed by the neighbourjoining method from $16 \mathrm{~S}$ rDNA sequences. Bootstrap support percentages from 1000 replications are indicated for each node. GenBank accession numbers are shown in parentheses. than $70 \%$, strongly suggested that D. suillum and Azospira oryzae belong to the same species.

In conclusion, the following observations, based on the analysis of type strains, demonstrate that D. suillum and Azospira oryzae belong to the same species: (i) the $16 \mathrm{~S}$ rDNA shows $99.9 \%$ similarity; (ii) the SDS-soluble proteins show almost identical patterns in electrophoregrams, which indicates a high degree of genomic similarity (Kersters, 1985); (iii) the two bacteria share most of the phenotypic characteristics tested, such as carbon source utilization, enzymic activities and diazotrophy, a key feature of the genus Azospira [the difference in a single characteristic, dissimilatory (per)chloride reduction, would not justify separation into two species or genera]; and (iv) the DNA-DNA binding level of $90-92 \%$ is well above the suggested limit for species identity.

The name Azospira oryzae was validly published in 2000 (Reinhold-Hurek \& Hurek, 2000), the taxon being first described as Azoarcus sensu lato group D in 1993 (ReinholdHurek et al., 1993), and 16S rDNA sequences were available in GenBank and published as a fragment in 1995 (Hurek \& Reinhold-Hurek, 1995) and as almost complete sequences in 1997 (Hurek et al., 1997a). However, neither Azoarcus sp. group D nor Azospira oryzae was included in phylogenetic analyses of D. suillum (Achenbach et al., 2001; Coates et al., 1999, 2001). Our data, however, provide evidence that D. suillum (Achenbach et al., 2001) is a later subjective synonym of Azospira oryzae (Reinhold-Hurek \& Hurek, 2000) within the $\beta$-subclass of the Proteobacteria. This extends the known habitats for Azospira oryzae, which was previously thought to harbour exclusively plant- and fungus-associated strains.

\section{Emended description of Azospira oryzae Reinhold-Hurek and Hurek 2000}

Azospira oryzae (o.ry'zae. N.L. fem. n. Oryza genus name of rice; N.L. gen. n. oryzae from rice, referring to its frequent occurrence in association with rice roots).

The following description is based on the data of Reinhold-Hurek et al. (1993), Reinhold-Hurek \& Hurek (2000) and Achenbach et al. (2001) and the data presented in this paper. On VM ethanol medium, colonies are translucent, pinkish to salmon-coloured, smooth, convex with an entire margin. Growth optimum at $37^{\circ} \mathrm{C}$. Sources of isolates are surface-sterilized roots of Gramineae such as Kallar grass [Leptochloa fusca (L.) Kunth] or rice (Oryza) species, grown in the Punjab of Pakistan or Nepal, Philippines and Italy, respectively, resting stages (sclerotia) of basidiomycetes (Pakistan) and (per)chlorate-reducing enrichments from samples collected from a primary treatment lagoon of swine waste in the USA.

The type strain is strain $6 \mathrm{a} 3^{\mathrm{T}}\left(=\mathrm{LMG} 9096^{\mathrm{T}}\right)$, which has a $\mathrm{G}+\mathrm{C}$ content of $65.2 \mathrm{~mol} \%$ and was isolated from Kallar grass. 


\section{Acknowledgements}

This research was funded by a grant from the BMBF (Bundesministerium für Bildung und Forschung) to B. R.-H. We thank Jessica Döring (Laboratory of General Microbiology, University Bremen) for assistance in anaerobic culturing techniques.

\section{References}

Achenbach, L. A., Michaelidou, U., Bruce, R. A., Fryman, J. \& Coates, J. D. (2001). Dechloromonas agitata gen. nov., sp. nov. and Dechlorosoma suillum gen. nov., sp. nov., two novel environmentally dominant (per)chlorate-reducing bacteria and their phylogenetic position. Int J Syst Evol Microbiol 51, 527-533.

Bruce, R. A., Achenbach, L. A. \& Coates, J. D. (1999). Reduction of (per)chlorate by a novel organism isolated from a paper mill waste. Environ Microbiol 1, 319-329.

Coates, J. D., Michaelidou, U., Bruce, R. A., O’Connor, S. M., Crespi, J. N. \& Achenbach, L. A. (1999). Ubiquity and diversity of dissimilatory (per)chlorate-reducing bacteria. Appl Environ Microbiol 65, 5234-5241.

Coates, J. D., Chakraborty, R., Lack, J. G., O'Connor, S. M., Cole, K. A., Bender, K. S. \& Achenbach, L. A. (2001). Anaerobic benzene oxidation coupled to nitrate reduction in pure culture by two strains of Dechloromonas. Nature 411, 1039-1043.

De Ley, J., Cattoir, H. \& Reynaerts, A. (1970). The quantitative measurement of DNA hybridization from renaturation rates. Eur J Biochem 12, 133-142.

Engelhard, M., Hurek, T. \& Reinhold-Hurek, B. (2000). Preferential occurrence of diazotrophic endophytes, Azoarcus spp., in wild rice species and land races of Oryza sativa in comparison with modern races. Environ Microbiol 2, 131-141.

Hurek, T. \& Reinhold-Hurek, B. (1995). Identification of grassassociated and toluene-degrading diazotrophs, Azoarcus spp., by analyses of partial $16 \mathrm{~S}$ ribosomal DNA sequences. Appl Environ Microbiol 61, 2257-2261.

Hurek, T., Burggraf, S., Woese, C. R. \& Reinhold-Hurek, B. (1993). $16 \mathrm{~S}$ rRNA-targeted polymerase chain reaction and oligonucleotide hybridization to screen for Azoarcus spp., grass-associated diazotrophs. Appl Environ Microbiol 59, 3816-3824.

Hurek, T., Wagner, B. \& Reinhold-Hurek, B. (1997a). Identification of $\mathrm{N}_{2}$-fixing plant- and fungus-associated Azoarcus species by PCRbased genomic fingerprints. Appl Environ Microbiol 63, 4331-4339.

Hurek, T., Egener, T. \& Reinhold-Hurek, B. (1997b). Divergence in nitrogenases of Azoarcus spp., Proteobacteria of the $\beta$-subclass. J Bacteriol 179, 4172-4178.
Jukes, T. H. \& Cantor, C. R. (1969). Evolution of protein molecules. In Mammalian Protein Metabolism, pp. 21-132. Edited by H. Munro. New York: Academic Press.

Karg, T. \& Reinhold-Hurek, B. (1996). Global changes in protein composition of $\mathrm{N}_{2}$-fixing Azoarcus sp. strain BH72 upon diazosome formation. J Bacteriol 178, 5748-5754.

Kersters, K. (1985). Numerical methods in the classification of bacteria by protein electrophoresis. In Computer-assisted Bacterial Systematics, pp. 337-368. Edited by M. Goodfellow, D. Jones \& F. G. Priest. London: Academic Press.

Maidak, B. L., Cole, J. R., Parker, C. T., Jr \& 11 other authors (1999). A new version of the RDP (Ribosomal Database Project). Nucleic Acids Res 27, 171-173.

Marmur, J. (1961). A procedure for the isolation of DNA from microorganisms. J Mol Biol 3, 171-173.

Michaelidou, U., Achenbach, L. A. \& Coates, J. D. (2000). Isolation and characterization of two novel (per)chlorate-reducing bacteria from swine waste lagoons. In Perchlorate in the Environment, pp. 271-284. Edited by E. T. Urbansky. New York: Kluwer/Plenum. Reinhold, B., Hurek, T., Niemann, E.-G. \& Fendrik, I. (1986). Close association of Azospirillum and diazotrophic rods with different root zones of Kallar grass. Appl Environ Microbiol 52, 520-526.

Reinhold-Hurek, B. \& Hurek, T. (2000). Reassessment of the taxonomic structure of the diazotrophic genus Azoarcus sensu lato and description of three new genera and new species, Azovibrio restrictus gen. nov., sp. nov., Azospira oryzae gen. nov., sp. nov. and Azonexus fungiphilus gen. nov., sp. nov. Int J Syst Evol Microbiol 50, 649-659.

Reinhold-Hurek, B., Hurek, T., Gillis, M., Hoste, B., Vancanneyt, M., Kersters, K. \& De Ley, J. (1993). Azoarcus gen. nov., nitrogen-fixing proteobacteria associated with roots of Kallar grass (Leptochloa fusca (L.) Kunth), and description of two species, Azoarcus indigens sp. nov. and Azoarcus communis sp. nov. Int J Syst Bacteriol 43, 574-584.

Saitou, N. \& Nei, M. (1987). The neighbor-joining method: a new method for reconstructing phylogenetic trees. Mol Biol Evol 4, 406-425.

Stackebrandt, E. \& Goebel, B. M. (1994). Taxonomic note: a place for DNA-DNA reassociation and $16 \mathrm{~S}$ rRNA sequence analysis in the present species definition in bacteriology. Int J Syst Bacteriol 44, 846-849.

Van de Peer, Y. \& de Wachter, R. (1994). TREECON for Windows: a software package for the construction and drawing of evolutionary trees for the Microsoft Windows environment. Comput Appl Biosci 10, 569-570. 